International Journal of Poultry Science 7 (1): xx-xx, 2008

ISSN 1682-8356

(C) Asian Network for Scientific Information, 2008

\title{
Productive Performance and Immune Response of Laying Hens as Affected by Dietary Propolis Supplementation
}

\author{
A. Galal', A.M. Abd El - Motaal ${ }^{2}$, A.M.H. Ahmed ${ }^{1}$ and T.G. Zaki \\ ${ }^{1}$ Department of Poultry Production, Faculty of Agriculture, Ain Shams University, Cairo, Egypt \\ ${ }^{2}$ Department of Poultry Nutrition Research, Animal Production Research Institute, \\ Agricultural Research Center, Giza, Egypt \\ ${ }^{3}$ Department of Poultry Breeding Research, Animal Production Research Institute, \\ Agricultural Research Center, Giza, Egypt
}

\begin{abstract}
An experiment was conducted to evaluate the efficacy of supplemental Propolis on productive performance and immune response of laying hens. One hundred and twenty Hy-Line White strain were divided into four groups of 30 each. They were fed 0, 50, 100 and $150 \mathrm{mg}$ of supplemental Propolis for 8 weeks (46-54wk). Chickens in all groups were reared under the same environmental, managerial and hygienic conditions. Feed and water were supplied ad libitum. The average high and low ambient temperatures recorded during the experimental period were 22.6 and $15.8^{\circ} \mathrm{C}$, respectively. The performance data revealed that the laying hens fed diet containing 100 and $150 \mathrm{mg}$ Propolis were significantly consumed more feed than control-group. Similar trend, but not statistically significant, was observed for hens fed diet added $50 \mathrm{mg}$ Propolis. With respect to egg mass, it could be noticed that the laying hens fed diet containing 100 and $150 \mathrm{mg}$ Propolis significantly produced heaviest egg mass compared to control-group. The hens fed diet added $50 \mathrm{mg}$ Propolis were intermediate. The increase feed intake and egg mass in propolis groups, resulting in significantly improve feed conversion ratio compared to control-group. Eggshell quality was significantly affected by Propolis supplementation, whereas the percentage and thickness of eggshell were significantly increased in the eggs produced from hens fed diet containing medium or high level of Propolis. In accordance to hematological parameters, the medium or high level of dietary Propolis significantly increased hematocrit level, plasma total protein and globulin. Conversely, the plasma cholesterol and liver enzymes were significantly reduced when laying hens fed diet containing 100 or 150 mg Propolis. In vivo cell-mediated immune response as measured by PHA-P stimulation (wattle) revealed that the laying hens fed diet added 50,100 and $150 \mathrm{mg}$ Propolis/ $/ \mathrm{kg}$ had significantly hyper responder compared to control-fed group. Concerning white blood cells differentiation, the present results speculated that the 100 and $150 \mathrm{mg}$ Propolis supplementation significantly decreased heterophils count and increased lymphocytes count when compared with the control-group. In conclusion, it can be concluded from the above study that supplementation of Propolis at 100 or $150 \mathrm{mg}$ is beneficial for improving the performance and immunity and for exploiting the full genetic potential of the commercial laying hens.
\end{abstract}

Key words: Laying hens, propolis, performance and immunocompetence

\section{Introduction}

Commercial laying hens are economic agriculture field production units in which the objective is to maximize field performance. Propolis, or "bee glue," is a wellknown substance that beekeepers find in their hives. There are many factors affecting propolis composition such as collecting location, time and plant source (Greenaway et al., 1991; Markham et al., 1996). Propolis according to research has shown to be effective against a variety of bacteria (Velikova et al., 2000), viruses (Amoros et al., 1994), fungi (Murad et al., 2002) and molds (Miyataka et al., 1997). It has been shown to be a non-specific immunostimulant (Dimov et al., 1991). Literature survey revealed that flavonoids, aromatic acids, diterpenic acids and phenolic compounds appear to be the principal components responsible for the biological activities of Propolis samples. Flavonoids are found in most fruits and vegetables, especially citrus fruits, onions, apples, kale, broccoli, grapes, red wine and tea. They act as antioxidants, prevent blood clotting and protect veins, lowering levels of harmful estrogen (Middleton and Kandaswami, 1993; Hanasaki et al., 1994; Duarte et al., 1993). The effect of Egyptian Propolis on chicken body weight and lymphoid organs, Hegazi et al. (1996) revealed an increase in body weight after one week post injection and increase thymus weight after 14 days post injection up to the end of the experiment. While spleen weight slightly affected, but bursa and caecal tonsils weights were increased at the last two weeks of the experiment. The highest phagocytic activity was at 14 days post injection with Propolis $(65 \%$ vs. $59 \%)$. Also, there was increase in the stimulation index 
Galal et al.: Dietary Propolis Supplementation

of the peripheral lymphocytes as detected by lymphocyte transformation in case of Propolis group. Hegazi et al. (1995) studied the effect of some bee products on immune response of chicken infected with virulent NDV. They found that, the mortality rate was reduced in-groups infected with virulent NDV and subsequently treated either with Propolis or honey if compared with the infected groups only. It was clear that, Propolis acts actively as antiviral agent than honey. The treatment with Propolis and honey of NDV infected chicken groups induced increase in the antibody titres and phagocytic percentage. Glinnik and Gapanovich (1981) showed that, in chickens, Propolis was effective against $S$. aureus and $S$. epidermidis in vitro. When Hubbard Golden comb hens were given a meal mixture containing 10, 20 and $30 \mathrm{mg}$ Propolis/ $/ \mathrm{kg}$ diet, Bonomi et al. (1976) reported that $30 \mathrm{mg}$ Propolis in diet significantly increased egg production, egg weight, feed utilization and weight gain by $6.07,1.27,5.46$ and $6 \%$ respectively, compared with control-group. In Ross broiler chicks, Shalmany and Shivazad (2006) indicated that average weight gain, feed consumption and feed efficiency were significantly higher for Propolis fed birds and inclusion of propolis also reduced mortality rate in comparison to control diet. Therefore, the present experiment was conducted to evaluate the efficacy of supplemental Propolis on productive performance and immune response of laying hens.

\section{Materials and Methods}

This experiment was carried out at poultry breeding farm, Poultry Production Department, Faculty of Agriculture, Ain Shams University. One hundred and twenty 50-wk-old, Hy-line White strain were randomly assigned to four groups of 30 hens each. The hens were individually housed in individually cages, on a 16hour light schedule. Chickens in all groups were reared under the same environmental, managerial and hygienic conditions. Feed and water were supplied ad libitum. The hens received a typical layer diet containing 2800 $\mathrm{ME} \mathrm{kcal} / \mathrm{kg}$ and $18 \% \mathrm{CP}$ to meet or slightly exceed the nutrient requirement recommended by NRC (1994). The hens were fed basal diet (control) or basal diet containing 50, 100 and $150 \mathrm{mg}$ Propolis $/ \mathrm{kg}$. The composition and calculated chemical analysis of the experimental diet are presented in Table 1. The average high and low ambient temperatures recorded during the experimental period were 22.6 and $15.8^{\circ} \mathrm{C}$, respectively.

\footnotetext{
Measurements and observations

Productive parameters: Body weight was individually recorded at 46, 50 and 54 weeks of age. Also, number and weight of eggs were recorded daily from the 46 to 54 weeks of age. Internal and eggshell quality was determined at 54 weeks of age. The egg length (long axis) and width (short axis) were measured with the
}

Table 1: Composition and calculated chemical analysis of the experimental diet

\begin{tabular}{lc}
\hline Ingredients & $\%$ \\
\hline Ground yellow corn & 61.80 \\
Soybean meal 44\% & 19.30 \\
Corn gluten meal & 2.90 \\
Decorticated cottonseed meal & 2.00 \\
Corn gluten feed & 4.00 \\
Bone meal & 1.80 \\
Limestone & 7.42 \\
Salt & 0.32 \\
Vitamin and mineral premix* & 0.40 \\
DL-Methionine & 0.04 \\
L-Lysine & 0.02 \\
Total & 100 \\
Calculated chemical analysis & \\
ME (kcal/kg) & 2800 \\
Crude protein (\%) & 18.00 \\
Crude fat (\%) & 2.90 \\
Crude fiber (\%) & 2.80 \\
Calcium (\%) & 3.75 \\
Available phosphorus (\%) & 0.40 \\
\hline
\end{tabular}

${ }^{*}$ Each $2.5 \mathrm{~kg}$ of vitamin and minerals premix contain: vit. A, 12 mIU; vit. $D_{3}, 4$ mIU; vit $E, 15 g$; vit. K, 2 ; vit. $B_{1}, 1 g$; vit $B_{2}, 8 g$; vit. $B 6,6 \mathrm{~g}$; vit $\mathrm{B}_{12}$, $10 \mathrm{mg}$; niacin, $30 \mathrm{~g}$; bioten, $150 \mathrm{mg}$; folic acid, 1g; pantothenic acid, 10g; choline chloride, $40 \mathrm{mg}$; zinc, $60 \mathrm{~g}$; manganese, $70 \mathrm{~g}$; iron, $15 \mathrm{~g}$; copper, $5 \mathrm{~g}$; iodine, $1 \mathrm{~g}$; selenium, $0.15 \mathrm{~g}$.

electronic caliper. The width to length ratio was shown in percentage points and constituted the egg shape index. The height of thick albumen $(\mathrm{H})$ and the egg weight $(\mathrm{W})$ were used to calculate Haugh units from the formula of Williams (1997): $\mathrm{HU}=100 \log \left(\mathrm{H}+7.7-1.7 \mathrm{~W}^{0.37}\right)$, where $\mathrm{H}=$ thick albumen height, $\mathrm{W}=$ egg weight. Yolk diameter along the chalazae line was determined with the caliper $(\mathrm{mm})$. The eggshell, after the removal of the egg content, was dried. Subsequently the eggshell was weighed to the nearest $0.01 \mathrm{~g}$. Eggshell thickness without inner membranes was measured $(\mathrm{mm})$ with the micrometer. The albumen weight was calculated from the difference between the entire egg weight and the yolk and eggshell weight. The contents of yolk, albumen and the eggshell were expressed as percentages from the weight of a fresh egg. The breaking strength was measured according to Fathi and El-Sahar (1996) which assessed the resistance of the egg to crushing.

Blood constituents: At 54 weeks of age, blood samples were taken from the brachial vein into heparinized tubes for all birds. A portion of the fresh blood was used for hematocrit determination using capillary tubes and a microhematocrit centrifuge. The hematocrit Figures were measured after spinning microhematocrit for $12 \mathrm{~min}$. Plasma was obtained from the blood samples by centrifugation for $10 \mathrm{~min}$. at $4000 \mathrm{rpm}$ and was stored at $-20^{\circ} \mathrm{C}$ until the time of analysis. The frozen plasma was allowed to thaw at room temperature prior to analysis. Plasma calcium, phosphorus, total protein, albumin, cholesterol, GOT and GPT were determined by 
Galal et al.: Dietary Propolis Supplementation

Table 2: Productive parameters of laying hens as affected by Propolis supplementation

\begin{tabular}{|c|c|c|c|c|c|c|c|}
\hline & \multirow[b]{2}{*}{ Age (wk) } & \multicolumn{4}{|c|}{ Propolis (mg/kg) } & \multirow{2}{*}{$\begin{array}{l}\text { Pooled } \\
\text { SEM }\end{array}$} & \multirow[b]{2}{*}{ Prob. } \\
\hline & & 0 & 50 & 100 & 150 & & \\
\hline \multirow[t]{3}{*}{ Body weight, $g$} & 46 & 1453.6 & 1450.2 & 1418.7 & 1453.9 & 51.45 & NS \\
\hline & 50 & 1469.7 & 1480.9 & 1440.8 & 1484.5 & 67.18 & NS \\
\hline & 54 & 1510.0 & 1500.3 & 1498.7 & 1512.2 & 57.83 & NS \\
\hline \multirow[t]{3}{*}{ Egg number, no. } & $46-50$ & $22.54^{b}$ & $22.84^{b}$ & $25.19^{\mathrm{a}}$ & $25.67^{a}$ & 0.31 & 0.01 \\
\hline & $50-54$ & $21.43^{c}$ & $22.32^{\mathrm{b}}$ & $25.12^{\mathrm{a}}$ & $25.81^{\mathrm{a}}$ & 0.25 & 0.01 \\
\hline & $46-54$ & $43.97^{c}$ & $45.16^{b}$ & $50.31^{a}$ & $51.48^{\mathrm{a}}$ & 0.30 & 0.01 \\
\hline \multirow[t]{3}{*}{ Egg weight, g } & $46-50$ & $61.53^{\mathrm{b}}$ & $61.69^{b}$ & $62.19^{a}$ & $62.60^{\mathrm{a}}$ & 0.22 & 0.01 \\
\hline & $50-54$ & $61.72^{\mathrm{b}}$ & $61.82^{b}$ & $62.93^{\mathrm{a}}$ & $63.10^{\mathrm{a}}$ & 0.23 & 0.01 \\
\hline & $46-54$ & $61.63^{b}$ & $61.76^{\mathrm{b}}$ & $62.56^{\mathrm{a}}$ & $62.85^{\mathrm{a}}$ & 0.20 & 0.01 \\
\hline \multirow[t]{3}{*}{ Egg mass, $g$} & $46-50$ & $1386.9^{c}$ & $1409.0 \mathrm{c}$ & $1566.6^{\mathrm{b}}$ & $1606.9^{a}$ & 15.22 & 0.01 \\
\hline & $50-54$ & $1322.7^{c}$ & $1379.8 \mathrm{c}$ & $1580.8^{b}$ & $1628.6^{a}$ & 21.14 & 0.01 \\
\hline & $46-54$ & $2709.9^{c}$ & $2789.1 \mathrm{c}$ & $3147.4^{\mathrm{b}}$ & $3235.5^{\mathrm{a}}$ & 27.16 & 0.01 \\
\hline \multirow[t]{3}{*}{ Feed consumption, g } & $46-50$ & $3298.7^{b}$ & $3268.9^{b}$ & $3321.3^{\mathrm{a}}$ & $3310.3^{\mathrm{a}}$ & 62.14 & 0.01 \\
\hline & $50-54$ & $3227.3^{b}$ & $3215.0^{b}$ & $3335.6^{a}$ & $3338.7^{\mathrm{a}}$ & 87.12 & 0.01 \\
\hline & $46-54$ & $6526.0^{b}$ & $6483.9^{b}$ & $6656.6^{a}$ & $6649.0^{\mathrm{a}}$ & 75.86 & 0.01 \\
\hline \multirow[t]{3}{*}{ Feed conversion ratio } & $46-50$ & $2.38^{a}$ & $2.32^{\mathrm{a}}$ & $2.12^{b}$ & $2.06^{\mathrm{b}}$ & 0.02 & 0.01 \\
\hline & $50-54$ & $2.44^{\mathrm{a}}$ & $2.33^{\mathrm{a}}$ & $2.11^{\mathrm{b}}$ & $2.05^{\mathrm{b}}$ & 0.01 & 0.01 \\
\hline & $46-54$ & $2.41^{\mathrm{a}}$ & $2.32^{\mathrm{a}}$ & $2.11^{\mathrm{b}}$ & $2.05^{b}$ & 0.02 & 0.01 \\
\hline \multirow[t]{3}{*}{ Egg production rate } & $46-50$ & $80.50^{b}$ & $81.57^{b}$ & $89.96^{a}$ & $91.68^{a}$ & 0.20 & 0.01 \\
\hline & $50-54$ & $76.54^{c}$ & $79.71^{b}$ & $89.71^{a}$ & $92.18^{a}$ & 0.32 & 0.01 \\
\hline & $46-54$ & $78.52^{c}$ & $80.64^{b}$ & $89.84^{a}$ & $92.57^{\mathrm{a}}$ & 0.28 & 0.01 \\
\hline
\end{tabular}

a,b,c Means within the same row with different letters are significantly differ.

Table 3: Interior and eggshell quality parameters as affected by Propolis supplementation

\begin{tabular}{|c|c|c|c|c|c|c|}
\hline \multirow[b]{2}{*}{ Item } & \multicolumn{4}{|c|}{ Propolis (g/kg diet) } & \multirow{2}{*}{$\begin{array}{l}\text { Pooled } \\
\text { SEM }\end{array}$} & \multirow[b]{2}{*}{ Prob. } \\
\hline & 0 & 50 & 100 & 150 & & \\
\hline Egg weight, g & $61.83^{b}$ & $62.01^{\mathrm{b}}$ & $63.14^{\mathrm{a}}$ & $63.45^{\mathrm{a}}$ & 0.25 & 0.01 \\
\hline Albumen, \% & 60.61 & 60.22 & 60.11 & 59.43 & 0.87 & NS \\
\hline Yolk, \% & 29.52 & 29.86 & 29.77 & 30.15 & 0.23 & NS \\
\hline Haugh unit & $81.56^{b}$ & $84.12^{\mathrm{a}}$ & 84.17 & $85.63^{\mathrm{a}}$ & 1.14 & 0.01 \\
\hline Shape index & 76.30 & 76.45 & 76.54 & 77.01 & 2.12 & NS \\
\hline Shell, \% & $9.87^{\mathrm{b}}$ & $9.92^{\mathrm{b}}$ & 10.12 & 10.42 & 0.36 & NS \\
\hline Shell thickness, mm & $0.320^{\mathrm{b}}$ & $0.323^{b}$ & $0.357^{\mathrm{a}}$ & $0.365^{\mathrm{a}}$ & 0.04 & 0.01 \\
\hline $\begin{array}{l}\text { Breaking strength, } \\
\mathrm{kg} / \mathrm{cm}^{2}\end{array}$ & $3.17^{b}$ & $3.26^{b}$ & $3.65^{\mathrm{a}}$ & $3.71^{\mathrm{a}}$ & 0.08 & 0.01 \\
\hline
\end{tabular}

$\overline{a, b}$ Means within the same row with different letters are significantly differ.

enzymatic colorimetric methods using available commercial kits. The plasma globulin was calculated as the difference between plasma total protein and albumin.

In vivo cell - mediated immunity: A phytohemagglutinin$\mathrm{P}$ (PHA-P) injection assay (Cheng and Lamont, 1988) was used to evaluate in vivo T-cell-mediated immune response of $\mathrm{Hy}$-Line laying hens. Birds were injected intradermally in the wattle with $0.5 \mathrm{mg}$ of PHA-P (Sigma Chemical Co., St. Louis, Missouri) in $0.1 \mathrm{ml}$ of phosphate buffered saline (PBS) after marking the injection site. The thickness of wattle was measured (to nearest $0.01 \mathrm{~mm}]$ ) at $0,24,48$ and $72 \mathrm{hrs}$ after PHA-P injection. Wattle swelling was calculated as the difference between the thickness of the wattle prior to and after injection of PHA-P.
Heterophils / lymphocytes ratio: At 54 week of age, blood samples were obtained from each treatment for heterophil $(\mathrm{H})$ and lymphocyte $(\mathrm{L})$ enumeration based on the procedures of Gross and Siegel (1983). Briefly, one drop of blood being smeared on each of glass slides. The smears were stained using Wright's stain. Two hundred leukocytes, including granular (heterophils) and nongranular (lymphocytes) ones, were counted on different microscopic fields representing 200 cells and the heterophil to lymphocyte ratio was calculated.

Statistical analysis: Data were subjected to a one-way analysis of variance with treatment group effect using the General Linear Model (GLM) procedure of SAS User's Guide, 2001. When significant differences among means were found, means were separated using Duncan's multiple range tests.

\section{Results and Discussion}

Productive parameters: Body weight, egg production parameters, feed consumption and feed conversion ratio of laying hens fed different levels of Propolis are summarized in Table 2. The present results revealed that there was no significant difference among treated groups for body weight. However, supplemental Propolis at 100 and $150 \mathrm{mg}$ significantly increased number and weight of eggs compared to control-group. These reflected on egg mass, whereas the hens fed diet containing 100 or $150 \mathrm{mg}$ Propolis produced significantly heaviest egg mass by 437.5 and $525.7 \mathrm{~g}$, respectively compared to control-group. Hubbard Golden 
Galal et al.: Dietary Propolis Supplementation

Table 4: Hematological parameters of laying hens fed different levels of propolis.

\begin{tabular}{|c|c|c|c|c|c|c|}
\hline \multirow[b]{2}{*}{ Item } & \multicolumn{4}{|c|}{ Propolis (mg/kg diet) } & \multirow{2}{*}{$\begin{array}{l}\text { Pooled } \\
\text { SEM }\end{array}$} & \multirow[b]{2}{*}{ Prob. } \\
\hline & 0 & 50 & 100 & 150 & & \\
\hline Hematocrit level,\% & $32.15^{b}$ & $32.56^{b}$ & $33.12^{\mathrm{a}}$ & $33.42^{\mathrm{a}}$ & 1.12 & 0.01 \\
\hline Total protein, g/dl & $5.67^{\mathrm{b}}$ & $5.68^{\mathrm{b}}$ & $6.18^{a}$ & $6.25^{\mathrm{a}}$ & 0.23 & 0.01 \\
\hline Albumin, g/dl & 3.57 & 3.44 & 3.51 & 3.23 & 0.10 & NS \\
\hline Globulin, g/dl & $2.10^{\mathrm{b}}$ & $2.24^{\mathrm{b}}$ & $2.67^{a}$ & $3.02^{\mathrm{a}}$ & 0.06 & 0.01 \\
\hline Calcium, mg/dl & 21.45 & 21.46 & 22.10 & 22.32 & 0.98 & NS \\
\hline Phosphorus, mg/dl & 10.12 & 10.43 & 10.51 & 10.17 & 0.45 & NS \\
\hline Cholesterol, mg/dl & $132.14^{a}$ & $131.12^{\mathrm{a}}$ & $125.46^{b}$ & $119.18^{c}$ & 3.14 & 0.01 \\
\hline GOT, U/L & $42.16^{a}$ & $41.35^{a}$ & $39.13^{b}$ & $38.75^{b}$ & 1.10 & 0.01 \\
\hline GPT, U/L & $12.14^{\mathrm{a}}$ & $12.10^{\mathrm{a}}$ & $10.48^{b}$ & $10.52^{b}$ & 0.65 & 0.01 \\
\hline
\end{tabular}

$a, b, c$ Means within the same row with different letters are significantly differ

comb hens aged 5.5 months were given a meal mixture without and with Propolis (10, 20 and $30 \mathrm{mg} / \mathrm{kg}$ diet), Bonomi et al. (1976) reported that supplemental $30 \mathrm{mg}$ Propolis in diet significantly increased egg production, egg weight, feed utilization and weight gain by $6.07,1.27$, 5.46 and $6.0 \%$ respectively, compared with control group. With respect to feed consumption and feed conversion ration, the present results indicated that the laying hens fed diet containing 100 and $150 \mathrm{mg}$ Propolis/kg diet were significantly consumed more feed than control-group. Similar trend, but not statistically significant, was observed for hens fed diet added $50 \mathrm{mg}$ Propolis. Moreover, the increase feed intake and egg mass in Propolis groups, resulting in significantly improve feed conversion ratio compared to controlgroup. Shalmany and Shivazad (2006) reported that chicks fed Propolis containing diets consumed significantly higher feed. Bonomi et al. (1976) found an increase in feed intake when laying hens were fed Propolis versus control groups. Also, they concluded that increase in feed intake in the Propolis groups may be due to improved birds health and higher palatability of Propolis diets due to mixture of resin, wax, honey and vanillin content of Propolis. Ghisalberti (1979) report additional weight gains for broiler chickens of up to $20 \%$ when $500 \mathrm{ppm}$ of propolis was added to their diets. They said that this improved effect is partially due to its high content of flavonoids and increase feed intake of Propolis diets than the control. Experimental work of Buhatel et al. (1983) showed that Propolis supplementation to the ration of pullets improved feed conversion. This effect is due to high content of flavonoids and healthy conditions of birds fed Propolis.

Internal and eggshell quality: Internal and eggshell quality as affected by Propolis supplementation is presented in Table 3. The egg weight was significantly affected by supplemental Propolis at 100 and $150 \mathrm{mg}$ compared to control-group. Similar trend, but not statistically significant, was observed for $50 \mathrm{mg}$ Propolis. There was no significant difference among treated groups for both albumen and yolk percentages. The Haugh units were significantly affected by Propolis supplementation, whereas the eggs produced from laying hens fed diet containing Propolis at all levels recorded the highest Haugh units compared to controlgroup. With respect to eggshell quality, it could be observed that both 100 and $150 \mathrm{mg}$ supplemental Propolis significantly increased the eggshell percentage compared to control-group. Similar trend was noticed for eggshell thickness, whereas the eggs produced from hens fed diet added 100 or $150 \mathrm{mg}$ Propolis recorded highest shell thickness compared to other group. In accordance to breaking strength, the present results showed that the breaking strength of eggs produced from hens fed diet containing 100 or $150 \mathrm{mg}$ Propolis significantly highest than those of other groups. It could be concluded that the supplemental Propolis at 100 or $150 \mathrm{mg}$ improved the eggshell quality.

Hematological parameters: Effect of supplemental Propolis on some blood parameters of laying hens are summarized in Table 4. The higher hematocrit level may have enhanced oxygen delivery to the tissue (Zongo and Petitjean, 1990). Also, this increase is supposed to be caused by increased blood volume as a reaction to increasing body oxygen requirement. The present result revealed that there was no significant difference between control and $50 \mathrm{mg}$ propolis diet for hematocrit level. Inversely, the hematocrit level of hens fed diet containing 100 or $150 \mathrm{mg}$ propolis was significantly higher than that of control-group. Also, it could be noticed that supplemental Propolis increased plasma calcium and phosphorus compared to control-group, but the difference did not statistically significant. With respect to plasma total protein, it could be speculated that the supplemental propolis at 100 or $150 \mathrm{mg}$ significantly increased plasma total protein compared to control group. Similar reports were drawn by Giurgea et al. (1981). They indicated that daily administration of propolis extract to chickens changed the blood concentration of cholesterol, total proteins and amino acid. Also, Propolis stimulated mammalian tissue regeneration, as it caused strong activation of mitosis of cells cultured in vitro and it enhanced protein biosynthesis (Scheller et al., 1977 and Gabrys et al., 
Galal et al.: Dietary Propolis Supplementation

Table 5: Wattle swelling (difference) of laying hens fed different levels of propolis

\begin{tabular}{|c|c|c|c|c|c|c|}
\hline \multirow[b]{2}{*}{ Time } & \multicolumn{4}{|c|}{ Propolis (mg/kg diet) } & \multirow{2}{*}{$\begin{array}{l}\text { Pooled } \\
\text { SEM }\end{array}$} & \multirow[b]{2}{*}{ Prob. } \\
\hline & 0 & 50 & 100 & 150 & & \\
\hline $24 \mathrm{hr}$ post $\mathrm{PHA}-\mathrm{P}$ injection & $0.31^{d}$ & $0.42^{\mathrm{c}}$ & $0.54^{\mathrm{b}}$ & $0.68^{\mathrm{a}}$ & 0.02 & 0.001 \\
\hline $48 \mathrm{hr}$ post $\mathrm{PHA}-\mathrm{P}$ injection & $0.22^{\mathrm{d}}$ & $0.36^{\circ}$ & $0.42^{\mathrm{b}}$ & $0.52^{\mathrm{a}}$ & 0.04 & 0.001 \\
\hline 72 hr post PHA-P injection & $0.08^{d}$ & $0.19^{c}$ & $0.30^{\mathrm{a}}$ & $0.36^{\mathrm{a}}$ & 0.01 & 0.001 \\
\hline
\end{tabular}

${ }^{a-d}$ Means within the same row with different letters are significantly differ.

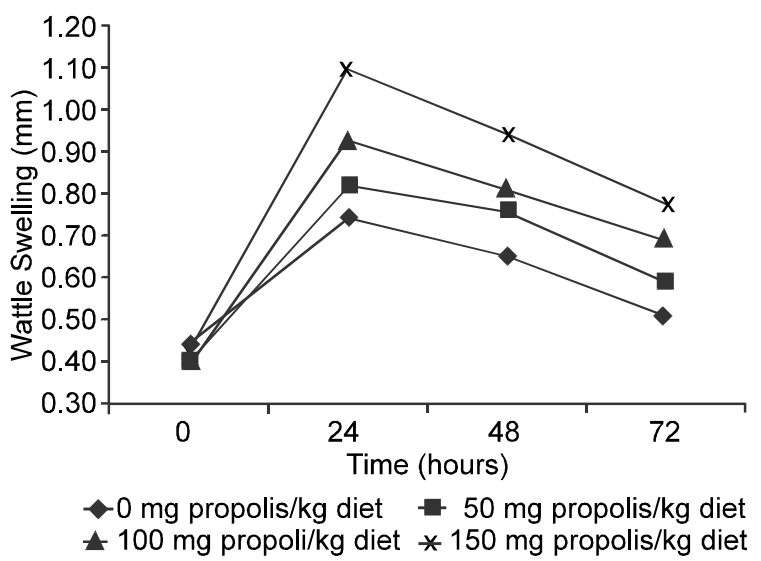

Fig. 1: Wattle swelling of laying hens as affected by propolis supplementation.

1986). Similar trend was not observed for albumin, whereas there was no significant difference among treated groups for plasma albumen. Concerning plasma globulin, our result revealed that the plasma globulin was significantly increased when the propolis added to the diet at 100 or $150 \mathrm{mg}$. The globulins are composed of three fractions, designated alpha, beta and gamma. Alpha-globulins are a group of proteins manufactured almost entirely by the liver. Normally, these proteins increase with acute nephritis, severe active hepatitis, active, usually systemic inflammation, malnutrition and in nephritic syndromes (Margaret, 2001). The gammaglobulin fraction contains most of the immuno-proteins, including $\lg M, \lg A, \lg E$ and $\lg G$. These usually elevate with ongoing antigenic stimulation, usually from infectious agents (Margaret, 2001).

There was no significant difference between 0 and 50 $\mathrm{mg}$ Propolis for plasma cholesterol. Inversely, the supplemental propolis at 100 and $150 \mathrm{mg}$ significantly reduced plasma cholesterol compared to control-group. With respect to liver function, it could be noticed that supplemental Propolis at 100 and $150 \mathrm{mg}$ significantly reduced GOT and GPT concentration compared to control-group. Hegazi et al. (1997) showed that, administration of Egyptian and Bulgarian propolis induces an antibacterial activity in vivo as well as in vitro. The ethanolic extract of propolis has a weak general effect on estimated parameters in normal rats and it is not a toxic substance. Both types of propolis exerted an anabolic effect for protein synthesis by liver cells. Both

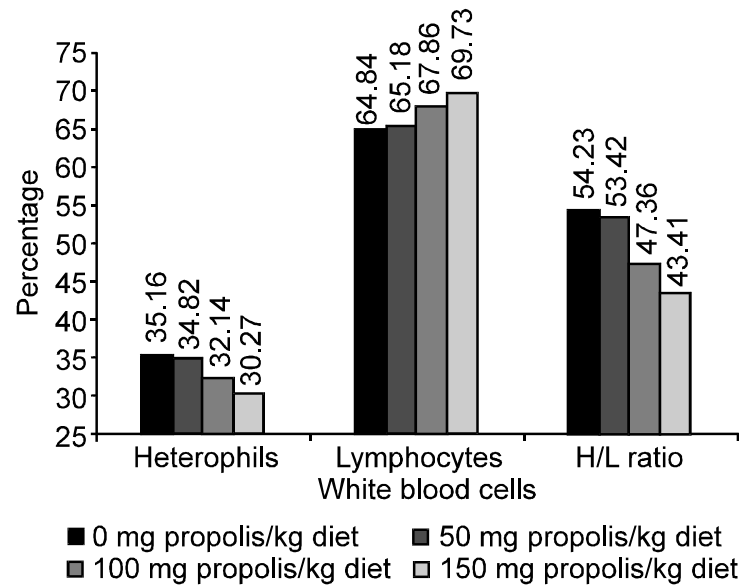

Fig. 2: Heterophils $(H)$, lymphocytes $(L)$ and $H / L$ ratio of laying hens fed different level of Propolis.

types of infections with $\mathrm{S}$. aureus and $\mathrm{E}$. coli caused an increase in the activity in serum AST and ALT and consequently decrease their activity in the liver. On the other hand, the activity of ALT and AST returned to the control level after administration of propolis in rats infected with S. aureus and E. coli.

\section{Immunocompetence parameters}

In vivo cell - mediated immunity: The PHA intradermally reaction, a T-lymphocyte-dependent response, has been well researched and has been shown to be a reliable indicator of in viva cellular immunity in poultry (Goto et al., 1978; McCorkle et al., 1980). The skin response reflects a complex series of physiological events such as mitogen-receptor and lymphocyte-macrophage interactions, release of chemical mediators, cellular proliferation and changes in vascularity (Chandra and Newberne, 1977). Histologically, PHA is strongly mitogenic to T-lymphocytesa and intradermali injections elicit macrophage infiltration and dense perivascular accumulations of lymphocytes $24 \mathrm{~h}$ post-injection in chickens (Goto et al., 1978; McCorkle et al., 1980). The increased infiltration by basophils and eosinophils $24 \mathrm{~h}$ post-injection has been described as a cutaneous basophil hypersensitivity response (Stadeckerm et al., 1977). In vivo cell-mediated immune response as measured by PHA stimulation (wattle) is presented in Fig. 1 and Table 5. It could be noticed that the hens fed diet added 50, 100 and $150 \mathrm{mg}$ Propolis/kg diet had significantly hyper responder to PHA-P injection 
Galal et al.: Dietary Propolis Supplementation

compared to control-fed group. Propolis according to research has shown to be effective against a variety of bacteria, viruses, fungi and molds. It has been shown to be a non-specific immunostimulant. The delayed hypersensitivity skin test using propolis as sensitizing antigen showed specific stimulation to propolis after 72 hours after inoculation with specific antigen. Egyptian propolis gave the typical delayed hypersensitivity when inoculated to the sensitized chickens. The thickness index was $0.90 \mathrm{~mm}$ thickness if compared with nonsensitized control group $0.12 \mathrm{~mm}$ thickness (Hegazi et al., 1996). Hegazi et al. (1995) studied the effect of some bee products on immune response of chicken infected with virulent NDV. They found that, the mortality rate was reduced in-groups infected with virulent NDV and subsequently treated either with propolis or honey if compared with the infected groups only. It was clear that, propolis acts actively as antiviral agent than honey. The treatment with propolis and honey of NDV infected chicken groups induced increase in the antibody titres and phagocytic percentage. The inoculation of different antigens in the footpad of sensitized and non-sensitized chickens induced different degrees of footpad thickness as well as cellular and vascular reaction depending on the type of inoculation with NDV antigen.

White blood cells differentiation: White blood cells differential count for laying hens fed different levels of propolis are presented in Fig. 2. It could be noticed that there was no significant difference between control and low level of propolis supplementation for both heterophils and lymphocytes count. Conversely, the medium and high level of propolis supplementation significantly decreased the heterophils count and increased the lymphocytes count when compared with the control-group. In birds, the heterophil are phagocytic cells whose main is protection against invading microorganisms, whereas primary functions of lymphoinvolve cell-mediated and humoral immunity. Heterophils increase and lymphocytes decrease when are stressed, so that the ratio between them is a index of response to a stressor (Gross and Siegel, 1985). In accordance to $H / L$ ratio, our results showed that the propolis supplementation at 2 and $3 \mathrm{~g} / \mathrm{kg}$ diet significantly increased the $H / L$ ratio of laying hens. The $\mathrm{H} / \mathrm{L}$ ratio is a recognized measure of stress in birds (Davison et al., 1983; Gross and Siegel, 1983; Maxwell, 1993) that has become a valuable tool in stress research especially when combined with the convenience and repeatability of automated blood cell counts.

In conclusion, it can be concluded from the above study that supplementation of Propolis at 100 or $150 \mathrm{mg}$ is beneficial for improving the performance and immunity and for exploiting the full genetic potential of the commercial laying hens.

\section{References}

Amoros, M., E. Lurton, J. Boustie, L. Girre, F. Sauvager, and M. Cormier, 1994. Comparison of the antiHerpes Simplex Virus activities of propolis and 3methyl-but-2-enyl caffeate. J. Nat. Prod., 57: 644647.

Bonomi, A., F. Morletto and M. Binachi, 1976. Propolis in feeds for laying hens. Avicoltura, 54: 43-54.

Buhatel, T., S. Vesa, A. Dimitrin and I. Moldovan, 1983. Contribution to knowledge of the stimulative effect of propolis on piglet and pullets. Buletinul Institului Agronomic Cluj Napoca Zootehnie Medicina Veterinara, 37: 45-48.

Chandra, R.K. and P.M. Newberne, 1977. Nutrition, immunity and infections. Plenum Press, New York.

Cheng, S. and S.J. Lamont, 1988. Genetic analysis of immunocompetence measures in a white Leghorn chicken line. Poult. Sci., 67: 789-995.

Davison, T.F., L.G. Rowell and J. Rea, 1983. Effects of dietary corticosterone on peripheral blood lymphocyte and granulocytes populations in immature domestic fowl. Res. Vet. Sci., 34: 236239.

Dimov, V., N. Ivanovska, N. Manolova, V. Bankova, N. Nikolov and S. Popov, 1991. Immunomodulatory action of propolis. Influence on anti-infectious protection and macrophage function. Apidologie, 22: 155-162.

Duarte, J., E.P. Vizcaino, P. Utrilla, J. Jimenez, J. Tamargo and A. Zarzuelo, 1993. Vasodilatory effect of flavonoids in rat aortic smooth muscles. Structure activity relationships. Biochem. Pharmacol., 24: 857-862.

Fathi, M.M. and E.A. EL - Sahar, 1996. Determining the strength of eggshell by using an appropriate apparatus and an equation to calculate egg surface depending on its dimensions. Egypt. Poult. Sci., 16: 285-303.

Gabrys, J., Z. Konecki, W. Krol, S. Scheller and J. Shani, 1986. Free amino acids in bee live product (propolis) as identified and quantified by gas Liquid chromatography. Pharmacol. Res. Commun., 18: 513-518.

Ghisalberti, E.L., 1979. Propolis: A review. Bee World, 60: 59-84.

Giurgea, R., V. Toma, H. Popescu and C. Linicencu, 1981. Effects of standardized propolis extracts on certain blood constituents in chickens. Clujul - Med., 54: 151-154.

Glinnik, A.V. and V.Y.A. Gapanovich, 1981. Antibacterial properties of propolis. Zhurnal Ushnykh Nosovykhi Gorlovykh Bolezner No., 4: 75-76.

Goto, N., H. Kodama, K. Okada and Y. Fujimoto, 1978. Suppression of phytohemagglutinin skin response in thymoectomized chicken. Poult. Sci., 57: 246-250. 
Galal et al.: Dietary Propolis Supplementation

Greenaway, W., J. May, T. Scaysbrook and F.R. Whatley, 1991. Identification by gas chromatography-mass spectrometry of 150 compounds in propolis. Zeitschrift fur Naturforschung, 42c: 111-121.

Gross, W.B. and P.B. Siegel, 1983. Evaluation of the heterophil/lymphocyte ratio as a measure of stress in chickens. Avian Dis., 27: 972-979.

Gross, W.B. and P.B. Siegel, 1985. Selective breeding of chickens for corticosterone response to social stress. Poult. Sci., 64: 2230-2233.

Hanasaki, Y., S. Ogawa and S. Fukui, 1994. The correlation between active oxygen scavenging and antioxidative effects of flavonoids. Free Radical Biol. Med., 16: 845-850.

Hegazi, A.G., H.F. El Miniawy and F.A. El Miniawy, 1995. Effect of some honeybee products on immune response of chicken infected with Virulent NDV. Egyptian J. Immuol., 2: 79-86.

Hegazi, A.G., M. Khalefa and E. Toussun, 1997. Influence of various types of propolis on some biochemical changes of normal and bacterial infected rats. International Symposium On Apitherapy, Cairo 8-9th, March, 1997.

Hegazi, A.E., F.A. El Miniawy and F.K. Abd El Hady, 1996. Influence of administration of propolis on chicken immune status. The Egypt. J. Immunal., 3: 111-116.

Margaret, A.W., 2001. Avian Plasma Proteins. http://www.exoticpetvet.net.

Markham, K.E., K.A. Mitchel, A.L. Wilkins, J.A. Daldy and Y. Lu, 1996. HPLC and GC-MS identification of the major organic constituents in New Zealand propolis. Phytochemistry, 42: 205-211.

Maxwell, M.H., 1993. Avian blood leukocyte responses to stress. World's Poult. Sci. J., 49: 34-43.

McCorkle, F., I. Olah and B. Glick, 1980. The morphology of the phytohemagglutinin-induced cell responsein the chicken'sw attle. Poult. Sci., 59: 616-623.

Middleton, E. and C. Kandaswami, 1993. The impact of plant flavonoids on mammalian biology: Implications for immunity, inflammation and cancer. In the flavonoids: Advances in Research Science 1986. J.B. Harborne, (Ed.). Chapman and Hall, London, UK., pp: 619-652.
Miyataka, H., M. Nishiki, H. Matsumoto, T. Fujimoto, M. Matsuka and T. Satoh, 1997. Evaluation of propolis. 1. Evaluation of Brazilian and Chinese propolis by enzymatic and physico-chemical methods. Biol. Pharm. Bull., 20: 496-501.

Murad, J.M., S.A. Calvi, A.M.V.C. Soares, V. Bankova and J.M. Sforcin, 2002. Effect of propolis from Brazil and Bulgaria on fungucidal activity of macrophage against paracoccidioides brasiliensis. J. Ethnopharm, 79: 331-334.

National Research Council, 1994. Nutrient Requirements of Poultry. 9th Revised Edn. National Academy Press, Washington, DC.

SAS Institute, 2001. SAS/STAT User's Guide Version 8.2 Edn. Statistics. SAS Institute Inc., Cary, NC.

Scheller, S., E. No Lewajka, M. Panasiewicz, D. Dzieka, J. Tustanowski and A. Stojko, 1977. Biological proprties and clinical application of proplis. IV. The action of ethanol extract of propolis on cells cultured in vitro. Arzneim Forsah., 27: 1547-1549.

Shalmany, S.K. and M. Shivazad, 2006. The effect of diet Propolis supplementation on Ross broiler chicks performance. Int. J. Poult. Sci., 5: 84-88.

Stadeckerm, J., M. Luk, C.A . Dvorak and S. Leskowitz, 1977. The cutaneous basophil response to phytohemagglutininin chickens. J. Immunol., 118: 1564-1568.

Velikova, M., V. Bankova, I. Tsvetkova, A. Kujumgiev and M.C. Marcucci, 2000. Antibacterial ent-kaurene from Brazilian propolis of native stingless bees. Fitoterapia, 71: 693-690.

Williams, K.C., 1997. Some factors affecting albumen quality with particular reference to Haugh unit score. World's Poult. Sci. J., 48, 1: 5-16.

Zongo, D. and M. Petitjean, 1990. Effects associated with the $\mathrm{Na}$ (naked neck) gene in the domestic cock. I. live weight, comb, haematocrit, sexual maturity and semen characters in temperature environment. Bulletin of Anim. Health Prod. Afr., 38: 3, 259-263. 